\title{
Metallurgy of Microalloyed 24 Carat Golds*
}

\author{
Christopher W Corti \\ Manager Technical Information and Development and Editor, Gold Bulletin \\ World Gold Council, Kings House, 10 Haymarket, London SWIY 4BP, UK
}

\begin{abstract}
Pure gold is relatively soft with a low yield point and this has several drawbacks in the fabrication of 24 ct gold jewellery, limiting design possibilities as well as making such jewellery prone to scratching and wear. In recent years, however, there have been a number of hardened 24 ct materials developed with finenesses of 99.5 - 99.9\%, some already in commercial production, where improved hardness and strength have been achieved by microalloying. This paper examines their metallurgy - the theoretical basis for hardening and some candidate alloying elements which could form the basis of microalloyed 24 ct golds. These are compared to known published information on the compositions and properties of actual microalloyed $24 \mathrm{ct}$ golds. The scope for adapting the microalloying approach to $22 \mathrm{ct}$ and other carat golds is also discussed.
\end{abstract}

The use of gold for adornment and decorative artifacts dates back several thousand years. The original gold jewellery was based on native gold found in sedimentary deposits such as river beds. The gold was generally impure, containing silver as the main impurity, typically from 1 up to $25 \%$ by weight, with possibly a little tin, copper and/or platinum $(1,2)$. This would have conferred some small solid solution hardening to the gold. Gold containing high silver of $25 \%$ or more was known as 'electrum' and was a pale lemon yellow colour.

As we know, pure metals tend to be soft and ductile and gold is the ultimate example, being very soft and the most malleable (ductile) of all pure metals (3). In the modern production of gold jewellery, this softness is of little advantage in jewellery manufacture (4) and a disadvantage in service when items are liable to distort, fracture and scratch and wear heavily during use. It is one of the main reasons why much gold jewellery is made from carat golds where alloying confers hardening as well as colour variation.

Gold jewellery is currently purchased mainly for adornment in the Western cultures whereas in the Eastern cultures it is bought primarily as a store of value, a readily tradeable investment in times of economic and political instability. This difference is reflected in the caratages of gold used in jewellery with high carat golds preferred in the East and low-medium carat golds preferred in the West, as shown in Table 1. 24 carat 'Chuk Kam' jewellery is dominant in the Chinese region. Chuk Kam - meaning pure gold - is defined in the main Oriental countries as a minimum of $99.0 \%$ gold. In others, it is defined as 99.5\% or higher (See Table 1 in Reference 5 ). The region consumes over 400 tonnes of gold per annum, about $15 \%$ of total world jewellery fabrication, and this figure is growing as the Chinese economy develops.

Table 1 Typical Caratages of Gold Jewellery

\begin{tabular}{ll}
\multicolumn{1}{c}{ Region } & \multicolumn{1}{c}{$\begin{array}{c}\text { Typical Caratage } \\
\text { (fineness) }\end{array}$} \\
$\begin{array}{l}\text { Oriental East } \\
\text { (China, Hong Kong, Taiwan) }\end{array}$ & $\begin{array}{l}24 \text { carat 'Chuk Kam' } \\
(99.0 \% \text { min) }\end{array}$ \\
India & 22 carat $(91.6 \%)$ \\
Arabic countries & 21 carat (87.5\%) \\
Europe - Southern * & 18 carat $(75.0 \%)$ \\
Europe - Northern, USA, etc** & $8-18$ carat (33.3 - 75.0\%) \\
* Portugal - 19.2 carat (80.0\%) & \\
*** For example, Germany - 8,14 and 18 carat; UK - 9 ct; USA - 10,14 and \\
18 carat
\end{tabular}

\footnotetext{
* This article is based on a paper presented at the Santa Fe Symposium on Jewelry Manufacturing Technology, held in Albuquerque, New Mexico, USA, 16-19 May, 1999
} 


\section{CARAT GOLD JEWELLERY}

Normal Chuk Kam 24 carat gold of 99.0 or $99.5 \%$ purity (with silver as the major impurity) is soft for jewellery purposes with a very low hardness of about $\mathrm{HV}$ 20 - 30 in the annealed, soft condition rising to only HV 50-80 in the cold worked condition. In contrast, a standard yellow 22 carat gold-copper-silver alloy has an annealed hardness of about HV 52, rising to about HV140 in the work hardened condition and an $18 \mathrm{ct}$ standard yellow gold-silver-copper alloy has an annealed hardness of HV 150, rising to HV 225 in the work hardened condition and even higher in the age-hardened condition (6). The importance of alloying in enhancing properties is evident. Clearly, the development of a 24 carat gold with enhanced mechanical properties, particularly strength and hardness, would be welcomed by the consumer.

Recognising this, World Gold Council (and its predecessor, Intergold) sponsored the development of an alloy of $99.0 \%$ purity back in the mid 1980s with considerably enhanced properties. Alloyed with 1\% titanium, a hardenable alloy known as '990 gold' was successfully developed. Its development is detailed in Gold Bulletin (7) and Gold Technology (8). Table 2 shows its main properties. As can be seen, it has a much higher hardness than pure gold and $22 \mathrm{ct}$ yellow gold in the soft, annealed condition and is similar to $22 \mathrm{ct}$ yellow in the work hardened condition, although still not as hard as 18 carat yellow. However, in the agehardened condition, it is very similar to the hardness values obtained in the $18 \mathrm{ct}$ material and is much superior to conventional 22 and 24 carat golds which are not age hardenable. Clearly, the development of '990' gold-titanium alloy represented a significant breakthrough in enhancing the properties of gold, hallmarkable as 24 carat.

Unfortunately, ' 990 ' gold has only really seen application in the watch industry, and is little used in the jewellery industry today, despite its potential.

\section{IMPROVED STRENGTH 24 CARAT GOLDS}

In recent years, a number of improved strength 24 carat golds have been developed (5, 9-13), some commercially available, and jewellery produced in these is in the market place, particularly in Japan - see Figure 1. These are listed, with their mechanical properties in Table 3 . They have virtually the same melting point, colour and density as normal pure gold.

It is evident from Table 3 that, whilst annealed hardness is usefully higher than that for normal pure gold, cold working results in significant hardness increases and that some materials may be further hardened by low temperature ageing heat treatment. Perhaps not surprisingly, the highest hardnesses are achieved in the lower purity golds of $99.5-99.7 \%$ fineness. Most can be cast but the best hardnesses are achieved in the wrought condition, often coupled with ageing treatments. An important practical point is that, as far as published information tells us, these materials cannot be remelted and recycled without loss of strength (9), as the hardening microalloying additions lose their effect on remelting. These stronger alloys do influence manufacturing processes. For example, machine-made chain can be made from them with less difficulty than with normal pure gold.

When compared to standard yellow carat golds, we can see that these improved $24 \mathrm{ct}$ golds approach the hardness of 22 ct gold in both annealed and cold worked conditions but are some way off the hardness values for 18 ct gold, despite claims by some manufacturers.

It is surprising that such improvements in strength and hardness can be achieved in gold with alloying additions of only $0.5 \mathrm{wt} \%$. or less. Such small alloying additions can be described as microalloying. It is instructive, therefore, to examine how such improvements are possible in microalloyed gold.

Table 2 Properties of '990 Gold'

\begin{tabular}{|c|c|c|c|}
\hline & $\begin{array}{c}\text { Annealed, } \\
800^{\circ} \mathrm{C}, 1 \mathrm{~h}, \mathrm{WQ}\end{array}$ & $\begin{array}{l}\text { Cold Worked, } \\
\text { (23\% reduction) }\end{array}$ & $\begin{array}{l}\text { Age Hardened, } \\
500^{\circ} \mathrm{C}, 1 \mathrm{~h}, \mathrm{WQ}^{*}\end{array}$ \\
\hline Hardness, HV & 70 & 120 & $170-240$ \\
\hline $0.2 \%$ Yield Strength, $\mathrm{MPa}$ & 90 & 300 & $360-660$ \\
\hline Tensile Strength, MPa & 280 & 340 & $500-740$ \\
\hline Ductility, \% elongation & 40 & $2-8$ & $2-20$ \\
\hline
\end{tabular}

* Range depends on whether aged in annealed, cold worked or aged and cold worked condition 
Table 3 Improved Strength 24 ct Golds

\begin{tabular}{|c|c|c|c|c|c|c|c|}
\hline Material & Manufacturer & Purity & $\begin{array}{l}\text { Annealed } \\
\text { Hardness, HV }\end{array}$ & $\begin{array}{l}\text { Cold Worked } \\
\text { Hardness, HV }\end{array}$ & $\begin{array}{l}\text { Strength, } \\
\mathrm{MPa}\end{array}$ & Ductility, \% & Comments \\
\hline $\begin{array}{l}\text { High Strength } \\
\text { Pure Gold }\end{array}$ & $\begin{array}{l}\text { Mitsubishi, } \\
\text { Japan }\end{array}$ & $99.9 \%$ & 55 & 123 & 500 & 2 & Castable \\
\hline TH Gold & $\begin{array}{l}\text { Tokuriki Honten, } \\
\text { Japan }\end{array}$ & $99.9 \%$ & $35-40$ & $90-100$ & - & - & Castable \\
\hline Hard 24 Carat & Mintek, S.Africa & $99.5 \%$ & 32 & $\begin{array}{c}100 \\
\text { Aged: } 131-142\end{array}$ & - & - & $\begin{array}{c}\text { Age } \\
\text { Hardenable }\end{array}$ \\
\hline PureGold & $\begin{array}{l}\text { Three O Co, } \\
\text { Japan }\end{array}$ & $99.7 \%$ & 63 & $\begin{array}{l}106 \\
\text { Aged: } 145-176\end{array}$ & - & - & $\begin{array}{c}\text { Castable, } \\
\text { Hardenable, } \\
\text { Chain }\end{array}$ \\
\hline $\begin{array}{l}\text { Uno-A-Erre } \\
\text { 24ct Gold }\end{array}$ & $\begin{array}{l}\text { Uno-A-Erre, } \\
\text { Italy }\end{array}$ & $\begin{array}{l}\text { (i) } 99.6 \% \\
\text { (ii) } 99.8 \%\end{array}$ & $\begin{array}{l}33 \\
62\end{array}$ & $\begin{array}{c}87 \\
118\end{array}$ & - & - & $\begin{array}{l}\text { Both used in } \\
\text { CW condition }\end{array}$ \\
\hline DiAurum 24 & $\begin{array}{l}\text { Titan, } \\
\text { UK }\end{array}$ & $99.7 \%$ & 60 (as cast) & 95 & - & - & Castable \\
\hline Pure Gold & - & 99.9 & 30 & 50 & $190-380$ & $\begin{array}{l}\text { Anneal: } 40 \\
\text { CW: } 1\end{array}$ & \\
\hline $\begin{array}{l}22 \mathrm{ct} \text { Yellow } \\
(5.5 \mathrm{Ag}-2.8 \mathrm{Cu})\end{array}$ & - & $91.7 \%$ & 52 & $100-138$ & $220-440$ & $\begin{array}{l}\text { Anneal: } 27 \\
\text { CW: } 3\end{array}$ & Castable \\
\hline $\begin{array}{l}18 \mathrm{ct} \text { Yellow } \\
(12.5 \mathrm{Ag}-12.5 \mathrm{Cu})\end{array}$ & - & $75.0 \%$ & 150 & $\begin{array}{l}190-225 \\
\text { Aged: } 230\end{array}$ & $520-900$ & $\begin{array}{c}\text { Anneal: } 40 \\
\text { CW: } 3 \\
\text { Aged: } 15\end{array}$ & $\begin{array}{l}\text { Castable, } \\
\text { Age } \\
\text { Hardenable }\end{array}$ \\
\hline
\end{tabular}

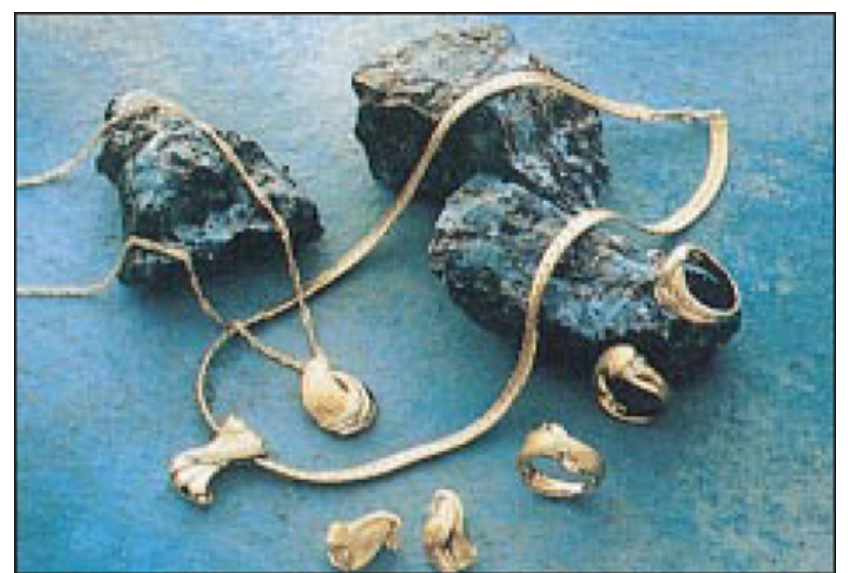

Figure 1 Jewellery in High Strength Pure Gold (9).

\section{BASIC MECHANISMS OF HARDENING}

Firstly, all metals and alloys are crystalline. All the metal atoms sit in a regular crystal lattice and a bulk alloy consists of many crystals - or grains, as metallurgists call them - each oriented in different directions. In pure gold, all atoms are gold atoms of exactly the same size and so the crystal lattice is regular, with flat, smooth crystal planes. The smaller the size of the crystals or grains in the alloy, the higher is the alloy strength. This is strengthening by grain size control - the Hall-Petch effect - where the flow strength is inversely proportional to the square root of the grain diameter.

In carat gold alloys, some of the gold atoms are substituted in the crystal lattice at random by atoms of the alloying metals, such as silver, copper and zinc. As atoms of different metals are of a different size, their inclusion in the lattice leads to a distortion of the lattice and the crystal planes become less smooth. Since deformation of the crystal takes place by the sliding of crystal planes over each other (through lattice defects known as dislocations moving through the lattice), any distortion of the lattice will increase the force necessary to slip the planes over each other. This is known as substitional solid solution strengthening. Silver atoms are a little larger in size than gold atoms whereas copper atoms are much smaller (by about 12\%) and cause greater distortion of the lattice. Hence copper is more effective than silver in strengthening gold - see Figure 2. In general, the more alloying atoms, the more the 
strengthening effect. That is why 22 carat $(91.7 \%$ gold) alloys are stronger than pure gold and 21, 18, 14 and lower carat golds even stronger.

As we all know, deforming or cold working a pure metal or alloy hardens it, a process known as work hardening. This has a limit as ductility reduces and eventually the material will fracture, if it is overworked. But some cold-working is a very effective way of improving the strength of pure gold and carat gold alloys. The only drawback is that the object must not be subsequently heated, for example, during soldering or by annealing, as this will cause any work hardening to be lost.

For many real alloys, it is not possible for atoms of alloying metals to substitute for the parent gold atoms beyond a certain concentration. Silver can completely substitute for gold at all concentrations, but in silvercopper alloys, for example, copper can only substitute in silver up to a limit which reaches a maximum of $8.8 \mathrm{wt} \%$ at $779^{\circ} \mathrm{C}$. Beyond that limit, a copper-rich phase is formed to yield an alloy consisting of two phases - a silver-rich phase and a copper-rich phase with different sized crystal lattices. A two-phase structure is normally stronger than a single phase structure. The degree of strengthening depends on the relative sizes of the different phases and their distribution.

In the case of gold - copper alloys, copper can substitute for gold in the solid phase at all concentrations above a temperature of about $410^{\circ} \mathrm{C}$. Below this temperature, one of two intermetallic compounds form at certain compositions and, depending on their size and distribution, can effect considerable strengthening to copper-containing carat golds up to about 18 carats fineness. These intermetallic phases are ordered structures in which the

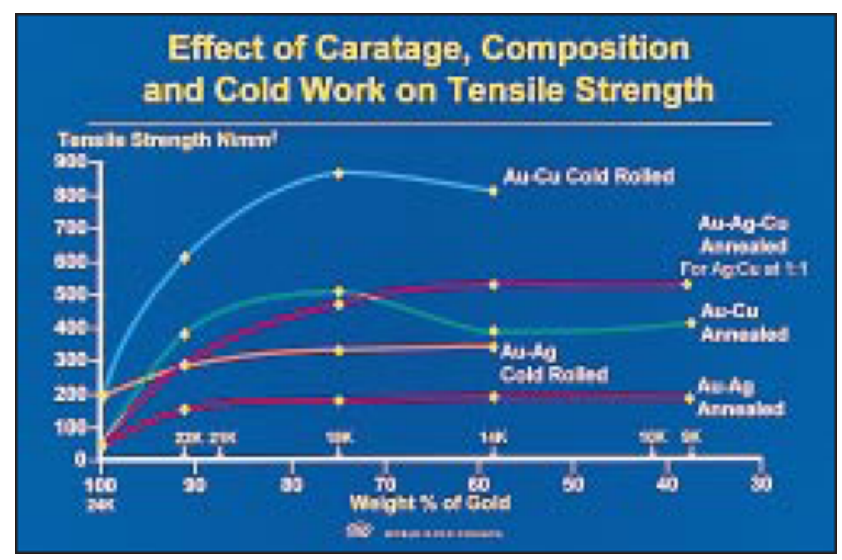

Figure 2 Effect of alloying and cold work on the properties of gold gold and copper atoms sit in specific sites in the crystal lattice (rather than at random, as in solid solution hardening). In this case, they form alternative layers of gold and copper atoms. This is a more difficult structure to deform and hence is harder.

The presence of hard, small particles of a second phase at grain boundaries or even within grains (or crystals) impedes the passage of dislocations - the crystal defects which enable deformation of the crystal under stress - through the crystal lattice and a higher force or stress is needed to deform the metal or alloy. This mode of strengthening is called dispersion hardening. These dispersions may be oxides or precipitates of second phases such as the ordered goldcopper intermetallic compounds (hence also known as precipitation hardening). The formation of such fine dispersions of precipitates of second phase can be controlled by low temperature heat treatment - often known as age hardening. Copper-containing goldsilver-copper alloys between 8 and 18 carats can be substantially hardened by such treatments.

The smaller the particles or precipitates and the more of them present, the greater the degree of strengthening. Thus, considerable strengthening can be obtained by relatively small volume fractions of particles provided they are very fine in size and well dispersed. This fact gives us a clue to the design of microalloyed 24 ct golds, since it is unlikely that significant strengthening of pure gold can be achieved from just control of grain size or solid solution hardening.

The use of small fractions of fine oxide particles to provide dispersion hardening of gold is reported in the literature $(14,15)$. Poniatowski and Clasing of Degussa reported (14) that a dispersion of $0.42 \%$ wt $(1.85 \%$ vol) $\mathrm{TiO}_{2}$ particles, $0.5 \mu \mathrm{m}$ diameter, gave an annealed hardness of HB 55, compared to HB 20 for pure gold, which rose to HB 80 after coldworking $80 \%$ reduction. Tensile strength was about $190 \mathrm{~N} / \mathrm{mm}^{2}$ compared to about $75 \mathrm{~N} / \mathrm{mm}^{2}$ for pure gold. Hill (15) of Engelhard, USA, studied mixtures of gold powder and oxides of thorium, aluminium, yttrium, cerium and titanium, to produce dispersions of oxides up to $1.00 \%$ by volume $(0.18-0.38 \% w t)$. Annealed hardnesses ranged from HV 51 - 65, which increased to HV $67-82$ after $82 \%$ cold work. The tensile strengths ranged from $153-207 \mathrm{~N} / \mathrm{mm}^{2}$ compared to $112 \mathrm{~N} / \mathrm{mm}^{2}$ for pure gold. These studies demonstrate that dispersion hardening can enable substantial hardening of gold at low concentrations.

Mention must be made of the difference between atom weight and size or volume. The higher atomic 
numbered metals are larger and also heavier. Gold is a heavy metal with a density of $19.3 \mathrm{~g} / \mathrm{cm}^{3}$ whereas silver has a density of $10.5 \mathrm{~g} / \mathrm{cm}^{3}$ and copper a density of $8.93 \mathrm{~g} / \mathrm{cm}^{3}$. Thus, in describing alloys we must differentiate compositions given in terms of weight per cent - the relative weights of alloying metals per cent and compositions given in terms of atomic per cent, ie how many atoms there are of each metal in the alloy. This is illustrated by gold-copper alloys. An alloy of $50 \%$ gold atoms and 50\% copper atoms, ie one gold atom to each copper atom, has a weight per cent composition of about $75 \%$ gold and $25 \%$ copper, reflecting the difference in weight of the gold and copper atoms!

\section{MICROALLOYING OF GOLD}

\section{The Theoretical Basis for Microalloying}

In the development of improved strength 24 carat golds, we are looking at total alloying additions of 0.5 wt $\%$ or less, even down to only $0.1 w t \%$ in some instances, to effect a dramatic strengthening of the gold crystal lattice. Such small additions are approaching those typically used to control grain size (the so-called 'grain refiners'). As gold is a low stacking fault metal (stacking faults are a type of crystal lattice defect), control of grain size alone or in combination with cold work will not yield significant hardening in pure gold, so such small additions cannot work through grain size control only.

The only way such small additions might contribute to significant solid solution hardening is if the alloying metal is very light, ie it has a low density and there is a large difference in atom size to gold. If we examine the Periodic Table, the light metals that might be possible microalloying additions are, in order of density: lithium, potassium, sodium, calcium, magnesium and beryllium, Table 4.

Table 4 Possible Light Metals for Alloying into Gold

$\begin{array}{lccc}\text { Metal } & \begin{array}{c}\text { Atomic } \\ \text { Number }\end{array} & \begin{array}{r}\text { Atomic } \\ \text { Weight }\end{array} & \begin{array}{r}\text { Density, } \\ \mathbf{g} / \mathbf{c m}^{\mathbf{3}}\end{array} \\ \text { Lithium } & 3 & 6.9 & 0.53 \\ \text { Potassium } & 19 & 39.1 & 0.86 \\ \text { Sodium } & 11 & 23.0 & 0.97 \\ \text { Calcium } & 20 & 40.1 & 1.53 \\ \text { Magnesium } & 12 & 24.3 & 1.74 \\ \text { Beryllium } & 4 & 9.0 & 1.85\end{array}$

Taking the lightest metal in Table 4, a gold $0.5 \mathrm{wt} \%$ lithium alloy, for example is $12.55 \mathrm{at} \%$ lithium which is within the solid solubility range. This is about 1 atom of lithium to every 7 atoms of gold. In comparison, a gold - 12.55 at $\%$ copper alloy is only $4.4 \mathrm{wt} \%$ copper which would increase hardness in the annealed condition to about HV40 and to about HV80 in the cold worked condition. So maybe a goldlithium alloy could provide the necessary property improvement by solid solution hardening, but it is doubtful.

If we look at another light metal, calcium, a gold $-0.5 \mathrm{wt} \%$ calcium alloy is only $2.41 \mathrm{at} \%$ calcium which is quite small - only 1 atom in 40 - and, therefore, would not be expected to provide much solid solution strengthening. However, reference to the phase diagram (see Figure 3) shows that there is virtually no solid solution of calcium in gold and that there is a eutectic comprising two phases of which one is gold and the other an intermetallic compound of high gold content, probably $\mathrm{Au}_{4} \mathrm{Ca}$ or possibly $\mathrm{Au}_{5} \mathrm{Ca}$.

If this latter phase is finely dispersed in the microstructure, then we have the basis of a possible alloy system which could provide improved properties through dispersion hardening. In the as-cast condition, we would anticipate a structure of primary dendrites of gold edged with regions of the eutectic mixture of the two phases. However, on cold working and annealing, this structure would be broken down and refined to yield gold grains pinned by fine particles of the second phase of intermetallic $\mathrm{Au}_{4} \mathrm{Ca}$ (or $\mathrm{Au}_{5} \mathrm{Ca}$ ).

We find similar features to the gold-calcium system in the phase diagram for the gold - potassium system, but less strongly (ie lower gold-containing intermetallic compounds) in the gold-beryllium, gold-magnesium and gold-sodium phase diagrams, suggesting that they are less favourable for a microalloying approach.

Another alloying approach would be to add the rare earth metals, such as cerium, lanthanum and dysprosium, as these also tend to have limited solid solubility in gold and to form eutectics and intermetallic compounds of high gold content. Table 5 lists some relevant features of their phase diagrams with gold. Some rare earths have been omitted for brevity. From this table, it can be seen that the light rare earths are potentially suitable. Figure 4 shows the phase diagram for gold-cerium. The similarity to the gold-calcium system at the gold-rich end is evident. Also, as the 'heavy' rare earths have a solubility at the eutectic temperature in excess of $0.5 \%$, but a very low solubility as the temperature 


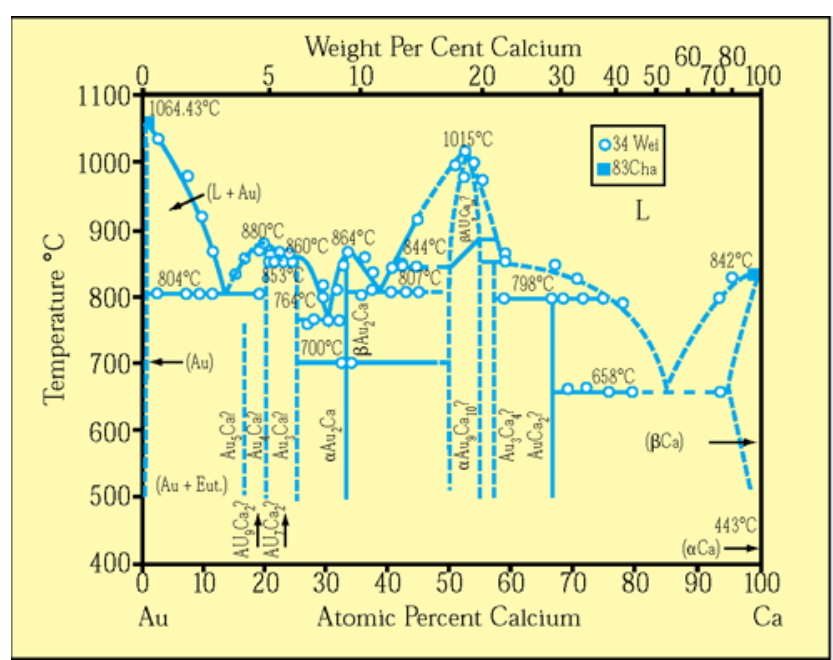

Figure 3 The gold-calcium phase diagram

falls, it is possible that they may be amenable to agehardening treatment with the precipitation of fine particles of the intermetallic on annealing quenched material at low temperatures. This is illustrated in Figure 5, which shows the region of solid solubility for gold-erbium alloys.

In the development of the 990 gold-titanium alloy, Gafner (7) describes work done by the Degussa company in Germany on other candidate alloy systems which included the heavy rare earths. The basis for selection was the possibility of second phase precipitation as an alloy containing a $1 \mathrm{wt} \%$ alloying addition in solution was cooled from 800 to $400^{\circ} \mathrm{C}$. From this, a table of probable hardening effectiveness

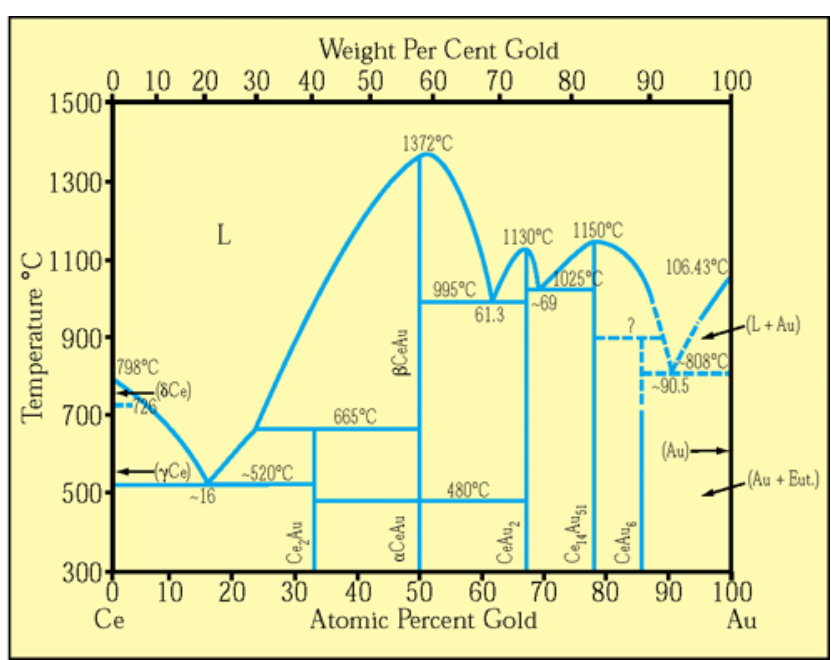

Figure 4 The gold-cerium phase diagram

was constructed, Table 6 . The fraction of hardening phase in the last column (calculated as the fraction of the $1 \%$ alloying addition precipitating in atomic percent multiplied by the number of atoms of the alloying addition in the precipitating intermetallic compound) was taken as an indication of hardening effectiveness. The reason for developing the 990 gold-titanium alloy is obvious from this table. The promise of the rare earths and zirconium should also be noted.

However, in this work, a $1 \mathrm{wt} \%$ alloying addition was being evaluated. If we consider only a $0.5 \mathrm{wt} \%$ addition of rare earth, then from the solubility data at $400^{\circ} \mathrm{C}$ in Table 5 , we cannot expect much hardening

Table 5 Features of Gold - Rare Earth Phase Diagrams

\begin{tabular}{|c|c|c|c|c|}
\hline Rare Earth & $\begin{array}{l}\text { Solid Solubility } \\
\text { in gold }\end{array}$ & $\begin{array}{l}\text { Intermetallic } \\
\text { compound }\end{array}$ & $\begin{array}{l}\text { Eutectic, at } \% \text { gold } \\
\text { (temperature, }{ }^{\circ} \mathrm{C} \text { ) }\end{array}$ & Comment \\
\hline Lanthanum & v.low & $\mathrm{Au}_{6} \mathrm{La}$ & $91(808)$ & OK \\
\hline Cerium & v.low & $\mathrm{Au}_{6} \mathrm{Ce}$ & $90.5(808)$ & OK \\
\hline Praseodymium & v.low & $\mathrm{Au}_{6} \mathrm{Pr}$ & $88(808)$ & OK \\
\hline Neodymium & v.low & $\mathrm{Au}_{6} \mathrm{Nd}$ & $90.5(796)$ & OK \\
\hline Samarium & v.low & $\mathrm{Au}_{6} \mathrm{Sm}$ & $88.5(770)$ & OK \\
\hline Gadolinium & low $(0.7$ at $\% *)$ & $\mathrm{Au}_{6} \mathrm{Gd}$ & $90.5(804)$ & Age-hardenable? \\
\hline Dysprosium & 2.1 at $\%^{*}$ & $\mathrm{Au}_{6} \mathrm{Dy}$ & $90.5(808)$ & Age-hardenable? \\
\hline Erbium & 5.7 at $\%^{*}$ & $\mathrm{Au}_{4} \mathrm{~Eb}$ & $88.6(734)$ & Age-hardenable? \\
\hline Terbium & 1.5 at\%* & $\mathrm{Au}_{6} \mathrm{~Tb}$ & $90.3(798)$ & Age-hardenable? \\
\hline Lutetium & 7.7 at $\%^{*}$ & $\mathrm{Au}_{4} \mathrm{Lu}$ & $84.8(890)$ & Age-hardenable? \\
\hline
\end{tabular}

* Solubility at the eutectic temperature; this reduces as the temperature falls. 
Table 6 Candidate Alloy Systems and Probable Hardening Effect, [from Gafner, reference (7)]

\begin{tabular}{|c|c|c|c|c|c|c|}
\hline System & $\begin{array}{l}\text { Solubility } \\
\text { at } 800^{\circ} \mathrm{C}\end{array}$ & $\begin{array}{l}\text { Solubility } \\
\text { at } 400^{\circ} \mathrm{C}\end{array}$ & $\begin{array}{l}\text { Fraction* } \\
\text { wt } \%\end{array}$ & $\begin{array}{l}\text { Ratio, } \\
\text { atomic weight }\end{array}$ & $\begin{array}{l}\text { Fraction* } \\
\text { at } \%\end{array}$ & $\begin{array}{c}\text { Fraction } \\
\text { hardening phase }\end{array}$ \\
\hline $\mathrm{Au}-\mathrm{Ti}$ & 1.2 & 0.4 & 0.6 & 4.1 & 2.5 & 12.5 \\
\hline $\mathrm{Au}-\mathrm{Rh}$ & 0.6 & 0.2 & 0.4 & 1.9 & 0.8 & 0.8 \\
\hline$A u-R u$ & 1.0 & 0.0 & 1.0 & 2.0 & 2.0 & 2.0 \\
\hline $\mathrm{Au}-\mathrm{Zr}$ & 2.0 & 0.3 & 0.7 & 2.2 & 1.5 & 7.5 \\
\hline $\mathrm{Au}-\mathrm{Tb}$ & 1.2 & 0.3 & 0.7 & 1.2 & 0.8 & 5.6 \\
\hline$A u-D y$ & 1.9 & 0.3 & 0.7 & 1.2 & 0.8 & 5.6 \\
\hline $\mathrm{Au}-\mathrm{Ho}$ & 3.2 & 0.4 & 0.6 & 1.2 & 0.7 & 4.9 \\
\hline $\mathrm{Au}-\mathrm{Er}$ & 4.8 & 0.4 & 0.6 & 1.2 & 0.7 & 3.5 \\
\hline
\end{tabular}

${ }^{*}$ Fraction of $1 \mathrm{wt} \%$ of alloying element precipitating at $400^{\circ} \mathrm{C}$.

phase to precipitate on annealing material which is in solution at $400^{\circ} \mathrm{C}$.

Fortunately, Degussa carried out some tests (16) on gold-rare earth alloys, at alloying levels of $1 \mathrm{wt} \%$ and lower. Cast alloys were annealed at $800^{\circ} \mathrm{C}$ for 1 hour. They were also cold rolled up to $95 \%$ deformation and subjected to age hardening treatments at a range of temperatures. Table 7 shows the hardness values attained for gold alloys containing $0.5 \%$ alloy or less. From this work, it can be seen that the annealed hardness is little different from normal pure gold, although cold worked material is much harder and in the range of the improved strength 24 carat materials (Table 3 ). Age hardening heat treatments are not very effective at these low concentrations with the exception of the $0.5 \%$ goldyttrium alloy (and yttrium is not strictly a rare earth

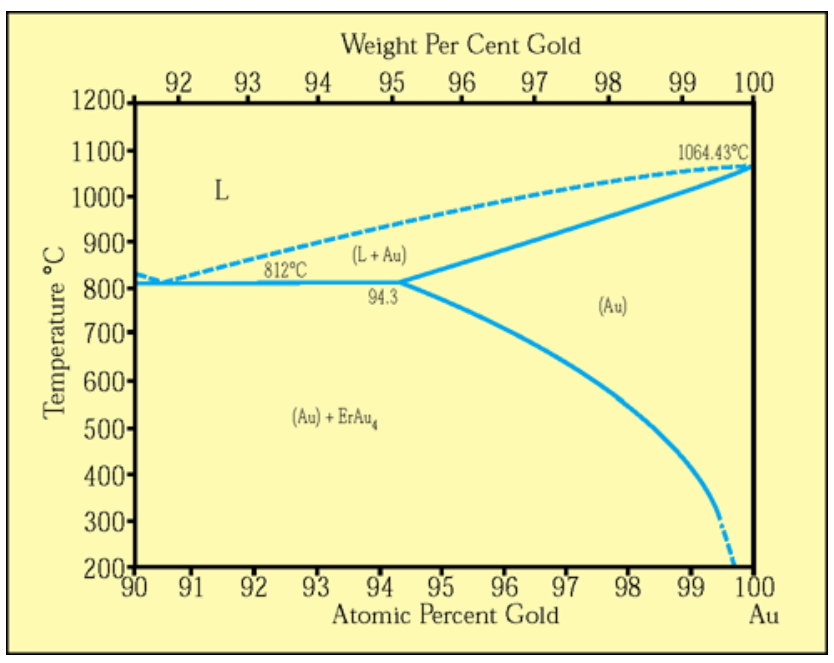

Figure 5 The limit of solid solubility at the gold-rich end of the gold-erbium phase diagram metal), confirming the view expressed earlier in that consideration of the solubility data, Table 5, of the heavy rare earths suggested little age hardening was possible at these low alloying levels. Whether alloys of gold with the light rare earths show good properties is not known from this work. It is difficult to comment on the results for gold-yttrium alloys as there is no published gold-yttrium phase diagram (17), but it may be expected to be similar to the light rare earths with little solid solubility of yttrium in gold.

\section{Compositions of Actual Improved Strength Golds}

The theoretical possibilities for microalloying gold have been discussed. But what do we know about the real materials. Unfortunately, few patents or papers have been published on the compositions of the materials that have been developed to date (Table 3 ). However, there is some information, mostly patents, which are now discussed.

\section{High Strength Pure Gold - Mitsubishi Materials Corporation}

Mitsubishi have several patents in this area. In their main patent (18), they claim gold alloys of $99 \%$ purity or higher containing 200 - 2000 ppm of one or more of the following elements: calcium, beryllium, germanium and boron. From other sources $(19,20)$, it is clear that calcium is the principal hardening metal in High Strength Pure Gold. Examination of the phase diagrams for gold-beryllium, gold-germanium and gold-boron shows similarities with gold-calcium, so similar effects on microstructure and properties are anticipated. The patent also includes further additions of $10-1000$ ppm of one or more of many metals including magnesium, 
Table 7 Ilardnesses of Gold - Rare Earth Alloys (from reference 14)

\begin{tabular}{|c|c|c|c|c|}
\hline $\begin{array}{l}\text { Alloy Composition , } \\
\text { wt } \%\end{array}$ & $\begin{array}{c}\text { Hardness, As cast, } \\
\text { HV }\end{array}$ & $\begin{array}{c}\text { Hardness, Annealed } \\
\text { HV }\end{array}$ & $\begin{array}{c}\text { Hardness, } 95 \% \mathrm{CW} \\
\mathrm{HV}^{*}\end{array}$ & $\begin{array}{c}\text { Hardness, Aged } 300^{\circ} \mathrm{C} \\
\mathrm{HV}^{*}\end{array}$ \\
\hline $\mathrm{Au}-0.3 \mathrm{Gd}$ & 44 & 30 & 130 & 63 \\
\hline $\mathrm{Au}-0.5 \mathrm{Gd}$ & 34 & 48 & 115 & 85 \\
\hline $\mathrm{Au}-0.5 \mathrm{~Tb}$ & 44 & 30 & 110 & 67 \\
\hline $\mathrm{Au}-0.5 \mathrm{Dy}$ & 70 & 29 & 120 & 75 \\
\hline$A u-0.3 Y$ & 35 & 24 & 110 & 45 \\
\hline$A u-0.4 Y$ & 32 & 34 & 120 & - \\
\hline $\mathrm{Au}-0.5 \mathrm{Y}$ & 61 & 38 & 145 & 174 \\
\hline
\end{tabular}

aluminium and cobalt and/or $10-1000 \mathrm{ppm}$ of rare earth metals and yttrium. The hardness values for over 50 alloys quoted in their patent lie typically in the range HV $100-140$ which is consistent with the claimed properties for High Strength Pure Gold.

In a further patent (20), an alloy of $99 \%$ gold or higher is claimed containing 500 - 2000 ppm calcium and $1-50 \mathrm{ppm}$ carbon. The role of carbon is not clear, but may harden interstitially or preferentially segregate with some calcium to grain boundaries.

\section{PureGold - Three O Company}

In their patent (11), an age hardenable alloy of $99.7 \%$ gold with a hardness comparable to an 18 carat gold is claimed containing $50 \mathrm{ppm}$ or more gadolinium and optionally a third metal - calcium, aluminium or silicon - the total being in the range $100-3000 \mathrm{ppm}$. For an alloy containing gadolinium and calcium, a maximum hardness after a combination of working and ageing of HV 176 is described which is consistent with the published hardness of PureGold, Table 3. The optimum ageing temperature is $250^{\circ} \mathrm{C}$.

\section{Other Golds}

From private discussions, it is clear that calcium is used in combination with other alloying metals in some of the other golds listed in Table 3. The basis for the Mintek Hard 24 ct Gold is unknown at the time of writing, but may be calcium or rare earths. In a patent from Tanaka KK, Japan (21), an alloy for precision casting is claimed containing small amounts of hafnium and rare earth metals.

In some reports $(9,10)$, the cold working of the surface during finishing plays an important role in hardening the surface.

\section{Other Literature}

Doped pure gold wires are used extensively in the electronics industry for bonding. In a recent paper (22), Lichtenberger and colleagues doped high purity gold (5-9's purity) with $3-30 \mathrm{ppm}$ of aluminium, calcium, copper, silver and/or platinum. They showed that most dopants strengthened the wire during extrusion (beryllium had the largest effect) but only calcium and beryllium had significant strengthening effects after annealing. This is explained on the basis of atom size difference in the gold lattice: Calcium atoms are about $30 \%$ larger and beryllium atoms are about $30 \%$ smaller than gold. There will be a tendency for calcium atoms to sit on grain boundaries and pin them at these low concentrations.

Various patents for improved strength gold bonding wires cite, respectively, additions of bismuth, rare earths, calcium with beryllium, europium with niobium, germanium, barium, yttrium with rare earths, and calcium with lead. The use of calcium, beryllium and/or the rare earths seems to be a popular choice in this application.

\section{APPLICATION TO 21 AND 22 CARAT GOLDS}

The microalloying approach discussed for improving the strength of 24 carat gold should also be applicable to high carat golds such as 21 or 22 carats, where agehardening by conventional alloying with copper is not viable. The copper and silver additions to high carat golds may influence the phase diagram characteristics described for the binary gold alloys, 
but the principles are still valid. However, there may also be scope for strengthening high carat golds by conventional alloying techniques. There is some evidence that cobalt additions are effective in conventional 22 carat gold. The recent announcement of an age hardenable Hard 22 ct Gold by Mintek (23) with hardnesses of up to HV 233 shows that it is possible, but as yet there is no indication of whether it is achieved by microalloying or by conventional alloying.

\section{CONCLUSIONS}

A number of improved strength 24 carat golds of at least $99.5 \%$ purity have been developed in recent years, using a microalloying approach. The theoretical basis for strengthening by such small amounts of alloying elements has been reviewed and some possible candidate alloying additions discussed on the basis of strengthening by precipitation hardening or a dispersed phase arising from a eutectic reaction during solidification. Subsequent refinement of the dispersed phase by cold working plays an important role. In general, the alloying addition should have a low solid solubility in gold at ambient temperatures and form an intermetallic compound of high gold content.

This alloying approach has been compared to known published information on the new 24 ct golds. The key alloying additions have been shown to include calcium, beryllium and the rare earth metals as suggested by the theoretical analysis.

The adoption of the microalloying approach to the high carat golds such as 21 and 22 carats is considered possible.

\section{ACKNOWLEDGEMENTS}

The contribution of many friends and colleagues in preparing this paper is appreciated. Thanks are also given to the World Gold Council for their support and permission to publish this paper.

\section{ABOUT THE AUTHOR}

Dr CW Corti, CEng, FIM, is a metallurgist with over 20 years experience in the precious metals industry. Prior to joining World Gold Council, he was with Johnson Matthey plc, initially as Research Manager, Materials Technology and later as Technical Director, Colour \& Print Division. He has also worked for the Department of Trade \& Industry in the UK, responsible for their surface engineering programmes, and for Brown Boveri in Switzerland.

\section{REFERENCES}

1 J. Ogden, Interdisciplinary Science Rev, 1992, 17 (3), 261-270

2 C.J. Raub, Gold Bull., 1973, 6, 51

3 J. Nutting and J.L. Nuttall, Gold Bull., 1977, 10, 2-8

4 J.C. Wright and C.W. Corti, Proc. Santa Fe Sympositum, 1997, 155-172; J.C. Wright and C.W. Corti, Gold Technology, No 23, April 1998, 27-34

5 M. DuToit, Proc. Santa Fe Symposium, 1997, 381- 394

6 See, for example, Gold Alloy Data Sheets in Gold Technology, № 1, January 1990, № 10, July 1993 and No 19, July 1996

7 G. Gafner, Gold Bull, 1989, 22, 112-122

8990 Gold', Gold Technology (complete issue), No 6, May 1992

9 A. Nishio, Gold Technology, No 19, July 1996, 11-14; S. Takahashi, N. Uchiyama and A. Nishio, Gold Technology, No 23, April 1998, 12-17

10 'The Move to Develop Stronger Gold', Report in Europa Star Magazine, November 1996,81

11 K. Ogasa, WO Patent 96/31632, 1995, Three O Company, Japan

12 Private Communication, 1995, H. McDermott, Titan Metals, UK

13 Private Communication, 1999, O. Caloni, UnoAErre, Italy

14 M. Poniatowski and M. Clasing, Gold Bull., 1972, 5, 34-36

15 J.S. Hill, Gold Bull., 1976, 9, 76-80

16 Progress Report to World Gold Council, Degussa AG, Germany. Reference R A 7/2, 1987

17 'Phase Diagrams of Binary Gold Alloys', ed. H. Okamoto and T.B. Massalski, ASM International, Metals Park, Ohio, 1987

18 N. Uchiyama, WO Patent 95/07367, 1993. Mitsubishi Materials Corporation, Japan

19 Private Communication, C.J. Raub, 1995

20 Japanese Patent 07265112A2, 1993, Mitsubishi Materials Corporation, Japan

21 Japanese Patent 7090425, 1993, Tanaka KK, Japan

22 H. Lichtenberger, H. Grohman, G. Lovitz and M. Zasowski, paper presented at IMAPS Conference, San Diego, USA, 1998

23 'Mintek Hard 22 Carat Gold', leaflet published 1998 by Mintek, Randburg, South Africa 